\title{
The Influence of Human Aspect of Accommodation and Destination on Tourist Satisfaction
}

\author{
Pantas H. Silaban, Arsen Pasaribu, Andri D. K. SIlalahi
}

\begin{abstract}
Tourism industry becomes a productive economic sector in the world. Nowdays, tourism industry in every country vary and is potentially to developed, especially in Indonesia. North Sumatera is one of the priority provinces for tourism development in Indonesia. One of the most popular tourism destinations in North Sumatera is Samosir Island Lake Toba. This research aims to analysis the influence of accommodation and destination in North Sumatera Tourism Industry. The population of this study is local tourist and international tourists visiting Tourist Destination in North Sumatera. Sample of this study is 250 respondents. Data analysis was used by software of Amos 22 with Structural Equation Modeling (SEM). The results of study prove that accommodation and destination have positively and significantly effeted to tourist satisfaction, the communication and hospitality of human aspect in providing services to the tourist are more concerned to improve. In terms of developing human aspect of accommodation and destination in North Sumatera, tourism industry needs to be focussed on two aspects, namely: hospitality and communication skill.
\end{abstract}

Proposed idea in improving the human aspect of the tourism industry is enchanging the creation of hybrid tourits satisfaction.

Keywords: Communication, Hospitality, Hybrid Tourist Satisfaction

\section{INTRODUCTION}

Tourism has been an activity of economics with highest increase rate in the world. The development of the industry reaches to approximately 2,57 trillion US in 2017. In fact, most of countries in the world have a productive asset of tourism to develop. The competitiveness of Indonesia in the tourism industry is being improved to $9^{\text {th }}$ from 50th in 2018, but still behind China and Singapore. In addition, UNWTO recorded that Indonesia is one of 10 countries in the world most competitive in managing tourism industry (UNWTO, 2018). In catching up growth rate of Indonesia tourism industry, its need to do development, such ability to generate the tourism satisfaction. The research of Parasuraman et all (1985) concluded that the rate of satisfaction is the outcomes of the comparison between perceived and required services. Perceived services of tourist are in accordance with the expected services, they will satisfy (Cronin et al, 2000). The main factor investigated in evaluating after - sales tourist destination is the tourist satisfaction (Oliver, 1981; Choi and Chu, 2001; Petrick, 2002, 2004). North Sumatera is one of the province, which has a potential tourism industry in Indonesia. In March 2018, the number of international tourists $^{\text {se }}$ visited North Sumatera still relatively low reach until 4,26\% from 2017. The realization of tourism marketing in North Sumatera is left far behind than other province in Indonesia. In addition, it can be a driving force for the growth in other related sectors (Tarmizi, et al, 2016). In the service industry, quality is a prerequisite to satisfy the consumers (Wood, 1991). For the tourism industry, satisfying the tourists is very important, because the tourist"s satisfaction is the basis for tourist loyalty and recommendation to other tourists (Tornow and Wiley, 1991). If the tourism marketers succeed in developing the high quality tourism services that satisfy the consumers, the company will gain a competitive advantage for its excellent services which are very difficult to replicate. An excellent service is a powerful weapon in the competition. In addition, it is also a competitive coup for the company (Howcroft, 1991; Berry and Parasuraman, 1991; Bennett and Higgins, 1988).

Traveler satisfaction is strongly affected by the service quality, perception and experience of tourism destination they visited. This research is intended to respond to the developments of the tourism environment in North Sumatera Province, which has potential tourism industry to grow. The focus of research is tourists from the international and national tourists that also become as the respondents. Furthermore, the tourism industry will be increased by offering a hybrid tourism services to the customers.

\section{LITERATURE REVIEW}

\subsection{Tourist Satisfaction}

Satisfaction is defined as a pleasurable feeling of fulfillment resulting from the customer's comparison of product performance to some pre purchase standard (Oviedo - García, Vega - Vázquez, Castellanos Verdugo \& Reyes Guizar, 2014). Baker and Crompton (2000) define tourist satisfaction as an individual emotional state after experiencing the trip. Understanding tourist satisfaction is of extreme importance for the tourism industry, particularly because of its effect on their future economic (Sadeh, Asgari, Mousavi, \& Sadeh, 2012). Gursoy, Mccleary, and Lepsito (2007) also acknowledge the value of tourist satisfaction in determining the success and continued existence of tourism business. This is mainly because tourist

satisfaction is a clear measure of how well an organizational product is doing in relation to a set of customer requirements.

\subsection{Tourist Destination and Tourist Satisfaction}

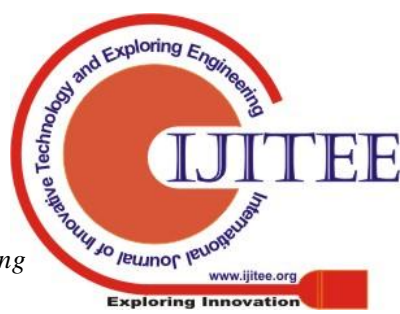




\section{THE INFLUENCE OF HUMAN ASPECT OF ACCOMMODATION AND DESTINATION ON TOURIST SATISFACTION}

Tourists $^{\text {ee }}$ satisfaction becomes a strategic variable for prescribing the destination. Destination can be defined as a geographical area consisting of all the services and infrastructure necessary for the stay of a specific tourist or tourism segment. Tourists' identification with a destination has been described as "the extent to which a tourist perceives a sense of connectedness to a destination and defines him or herself in terms of that feeling"(Hultman, Skarmeas, Oghazi, \& Beheshti, 2015, p.2228).

\section{$H_{1}$ : Tourist Destination has a positive and significant effect on tourist satisfaction}

\subsection{Accomodation and Tourist Satisfaction} Accommodation is a stay facility that is used to meet the needs of tourists, both regularly and at any time. Victor et. al (2009) defined tourist accommodation as "all establishments offering overnight accommodation on a commercial or „quasi-commercial ${ }^{\text {ee }}$ basis to all categories of visitor. The definition does not cover the use of privately-owned accommodation for weekends and holidays, such as second homes, caravans, chalets, boats and wholly-owned apartments in condominiums - unless they are commercially rented through a marketing agency". They explained about „Quasi-commerciale which "refers to the many tourist accommodation products outside the commercial sector, for which a charge is made to contribute to cost" (P. 364). Concerning this definition for accommodation, school stay can be included in the list of accommodation.

$\mathrm{H}_{2}$ : Accommodation has a positive and significant effect on tourist satisfaction

\section{CONCEPTUAL FRAME WORK}

The combination of both researches resulted in this research model and it is aimed at studying the relationship between the exogenous variables; accommodation, and destination to endogenous variables tourist satisfaction as shown in Figure 3.1.

Figure 3.1. Conceptual Framework

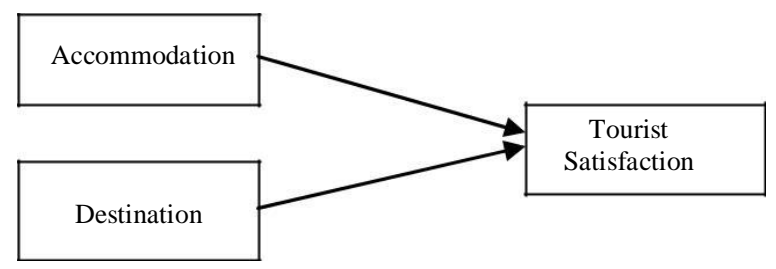

\section{RESEARCH METHODOLOGY}

It is an explanatory survey research, a research which explains, describes and provides empirical evidence or clear illustration on the effect of the influencing variables. The population of this research is the tourists visiting North Sumatera from international and local communities. Any firstly met tourists and those who meet the criteria were directly selected as the respondents or first unit sample, and those who were secondly met were selected to be the second respondents. It is continued until obtaining 250 tourists.
From the 250 questionnaires distributed, there were 234 questionnaires which can be re-collected. After checking the completeness of the questionnaire completion, there was a list of 198 questionnaires which is completed and able to process. The data analysis method used to test the hypothesis in this study is SEM (Structural Equation Model) with Amos

The excellence of SEM is due to its ability to present a comprehensive model along with the ability to confirm the dimensions of a construct or a factor as well as the ability to measure the effect of a relationship theoretically.

The implementation model can be described by the following equation:

$$
\mathrm{Y}=\gamma_{11} \mathrm{X}_{1}+\gamma_{12} \mathrm{X}_{2}+c_{\zeta}
$$

Where :

$\mathrm{s}=$ Measurement Error (epsilon) Construct (ksi)

$\gamma=$ Parameter (gamma) $\mathrm{Y}=$ Tourist Satisfaction

$\mathrm{X}_{1}=$ Accommodation

$\mathrm{X}_{2}=$ Destination

The evaluation model will be used goodness of fit criteria as is shown table below.

Table 2.1. The Evaluation of GOF Criteria

\begin{tabular}{ll} 
Goodness of Fit & Cut of Value \\
\hline Chi - Cquare & Expected to be low \\
Probability & $\geq 0,05$ \\
RSMEA & $\leq 0,08$ \\
GFI & $\geq 0,90$ \\
AGFI & $\geq 0,90$ \\
CFI & $0<$ GFI $<1$ \\
TLI & $\geq 0,95$ \\
CMIN/DF & $\leq 2,00$ \\
\hline
\end{tabular}

\section{RESULT AND DISCUSSION}

1. The Spot of Heaven on Earth Tourist Destination in Lake Toba, North Sumatera

North Sumatera become the priority of tourism development in Indonesia. The main tourism destination in North Sumatera to foccused on development is Lake Toba. Lake Toba also become one of the most largest lake in the world which has many attractions and most of international and national tourist interested to visit in Indonesia. There is one place in Lake Toba have many attraction such as cultural tourism, water activities, climbing activities that tourist can attract themselves called Samosir Island. Samosir

Island has an authenticity become one of the most island that formed by largest vulcano event thousands years ago. 


\section{Data Analysis}

The research result on figure 5.1. is the model that shows the test of exogeneous variable to endogenous variable.

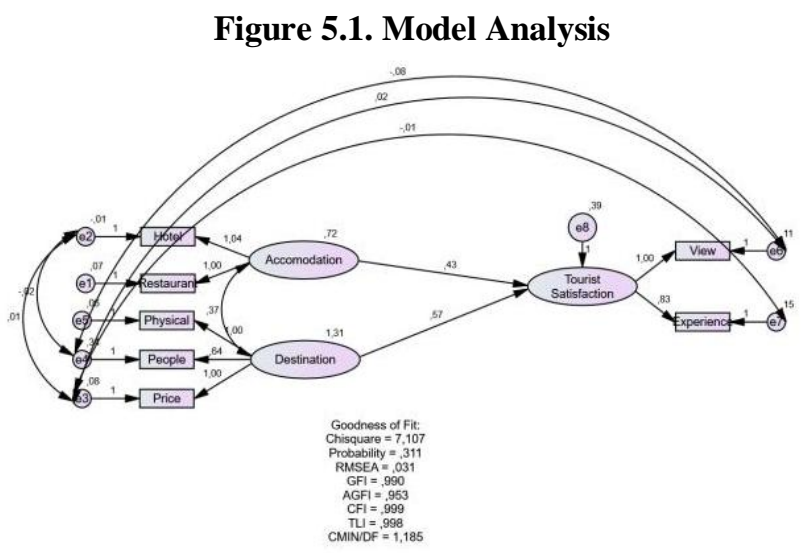

The model shown in figure 5.1. resulting the Goofness of Fit index such as Chi square $=7,107$, probability $=0,311$, RMSEA $=0,031$, GFI $=0,990$, AGFI $=0,953$, CFI = 0,999, $\mathrm{TLI}=0,998$ and $\mathrm{cmin} / \mathrm{df}=1,185$. All the index of Goodness of Fit model are fitted.

Hipothesis test shown in table 5.1.

Table 5.1. Hypothesis Test

\begin{tabular}{|l|c|r|c|c|}
\hline Path Way & $\begin{array}{c}\text { Cut Off } \\
\text { Value }\end{array}$ & CR & P-Value & Decision \\
\hline $\mathrm{X} 1$---- > Y & 1,96 & 6,969 & $* * *$ & Supported \\
\hline $\mathrm{X} 2$---- > Y & 1,96 & 11,667 & $* * *$ & Supported \\
\hline
\end{tabular}

The hypotesis result can be elaborate as follows:

1. The effect of accommodation on tourist satisfaction

The analysis of the research data has shown that accommodation has a positive and significant effect on tourist satisfaction. Throughout eleven indicators of accommodation respondents indicates that hospitality of waitress unsatisfactorily $80 \%$ of respondents and the communication of the waitress of restaurant unsatisfactorily $61 \%$ of respondents. The two aspects mentioned above relate to the human aspect of the tourism. The results of this research showed important things that can be concerned by the stakeholders of tourism accommodation. Tourist industry players need to focus their attention toward the improvement of the quality of service in the aspect of human resources both in the hospitality aspect and in the communication aspect as shows by the findings of this research.

2. The effect of destination on tourist satisfaction

The results of data analysis in this research shows that destination has a positive and significant effect on tourist satisfaction. Throughout nine indicators of destination respondents indicate that there are three indicators considered less-satisfactory, they are; friendliness of the local people unsatisfactorily $81 \%$ of respondents, and communication of the tourist guides unsatisfactorily $65 \%$ of respondents.

These results showed that there are two important things that should be concerned by the stakeholders in the tourist destination in North Sumatera. Tourist stakeholders must be concern of human resources or local people in order to improve the service quality of the tourist. Secondly, the communication still has a negative response by the respondent. Touristse stakeholders need to improve their communication to create a tourist satisfaction as shown in this research findings.

3. Social Innovation as a means to improve the quality of human resources in the tourism industry.

The intended social innovation is a variety of combinations of social interactions from two or more different cultural backgrounds that produce social interactions that improve and enhance openness thinking towards increasing creativity in social action. Open-minded can be defined as a way interacting with others and different background people openly that one can contribute to the improvement of creative abilities which lead to the improvement of communication quality and hospitality. The open minded must come from the tourism itself and the people who provide tourism service. When both of them are open- minded. It is hoped it will lead to the creation of hybrid tourism satisfaction. Which roughly defined as satisfaction obtained during the experience of tourism satisfaction beyond the definition proposed by scholars. Adding up with additional satisfaction from the realization of contribution towards the improvement of communication and hospitality of tourism people in the destination. The hybrid tourism satisfaction idea will be interestingly challenging for curious researcher.

\section{CONCLUSION}

In developing human aspect of accommodation and destination in North Sumatera, tourism industry needs to focus on two aspects namely hospitality and communication skill. Proposed idea in improving the human aspect of the tourism industry is enchanging the creation of hybrid tourits satisfaction.

\section{REFERENCES}

[1] Bennett, David and Higgins, M., 1989. Quality Means More than Smiles, ABA Banking Journal. 2(2). pp.234-245.

[2] Berry, Leonard L., and Parasuraman, A., 1991, Marketing Services: Competing Through Quality. New York The Free Press.

[3] Choi, T. Y., \& Chu, R. 2001. Determinats of Hotel Guests Satisfaction and Repeat Patronage in The Hong Kong Hotel Industry. International Journal of Hospitality Management 20(3). pp.277-297.

[4] Cronin, J., Brady, M., \& Hult, T. (2000). Assessing the effects of quality, value, and customer satisfaction on consumer behavioral intentions in service environments. Journal of Retailing, 76(2). pp.193-218.

[5] Gursoy, Mccleary, and Lepsito (2007). Propensity to Complain: Effects of Personality and Beharvioral Factors. Journal of Hospitality \& Tourism Research.

[6] Howcroft,J.B., 1991, Customer Satisfaction in Retail Banking.: The Service Industries Journal". 1(1). pp.12-24. 


\section{THE INFLUENCE OF HUMAN ASPECT OF ACCOMMODATION AND DESTINATION ON TOURIST SATISFACTION}

[7] Hultman, Skarmeas, Oghazi, \& Beheshti, (2015). Achieving Tourist Loyalty Through Destination Personality, Satisfaction and Identification. Journal of Business Research. 68 (11) $2227-2231$

[8] Parasuraman, A. Zeithaml, V. Berry L. (1985) A conceptual model of service quality and its implications for future research. Journal of Marketing, 49(4). pp.41 - 50.

[9] Petrick, J. F. 2002. Experience use history as a segmentation

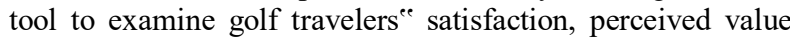
and repurchase intentions. Journal of Vacation Marketing, 8(4). pp.332-342.

[10] Petrick, J. F. 2004. The roles of quality, value, and satisfaction in predicting cruise passengers ${ }^{e e}$ behavioural intentions. Journal of Travel Research, 42(1). pp.397-407.

[11] Oliver, R., 1981. Measurement and evaluation of satisfaction processes in retail settings. Journal of Retailing, 57(3). Pp. $25-48$.

[12] Oviedo -,García, Vega \& Reyes, 2014. Travel Motivation and Tourist satisfaction With Wildlife Tourism Experiences in Gonarezhou and Matusadona National Parks, Zimbabwe. Journal of Outdoor Recreation and Tourism. Vol. 20, 2017. Pp. $1-18$

[13] Sadeh, Asgari, Mousavi, \& Sadeh, 2012. Factors Affecting Tourist satisfaction and Its Concequances. Journal of Basic and Applied Scientific Research. 2 (2) 1157 - 1560

[14] Tarmizi, H.B.,Daulay, M and Muda, I. 2016. The influence of population growth, economic growth and construction cost index on the local revenue of tax on acquisition of land and building after the implementation of law no. 28 of 2009. International Journal of EconomicResearch.13(5). pp. 22852295.

[15] Tornow, Walter W., and Wiley, Jack W., 1991. Service Quality and Management Practices: A look at Employe Attitudes, Customer Satisfaction, and Bottom-Line Consequences. Human Resource Planning.

[16] Victor T. C. Middleton, Alan Fyall, Michael Morgan, Ashok Ranchhod (2009) Marketing in Travel and Tourism. Elsevier Ltd.

[17] Wood, Susan B., 1991. Using Service to Outprform the Competition, New Jersey. Bank Marketing. 